\title{
PEMULIHAN (RECOVERY) DAN PEMISAHAN SELEKTIF LOGAM BERAT (Zn Cu dan Ni) DENGAN PENGEMBAN SINERGI MENGGUNAKAN TEKNIK SLM
}

\author{
M. Cholid Djunaidi, Mudji Triatmo, Gunawan \\ Laboratorium Kimia Analitik Jurusan Kimia \\ Fakultas MIPA Universitas Diponegoro Semarang 50275
}

\begin{abstract}
ABSTRAK
Telah dilakukan pemisahan logam berat $(\mathrm{Zn} \mathrm{Cu}, \mathrm{Ni})$ dengan menggunakan pengemban/pembawa sinergi yaitu campuran TBP (tributil fosfat) dan D2EHPA (asam di-2 etil heksil fosfat) dengan perbandingan 1:4 (1 M) dalam alat pemisahan SLM selama 4 jam. Analisa dilakukan dengan mengukur konsentrasi logam di fasa umpan dan penerima menggunakan AAS dan konsentrasi ion hidrogen menggunakan $\mathrm{pH}$ meter. Hasil analisa disimpulkan bahwa transport logam dari fasa umpan ke fasa penerima dipengaruhi oleh konsentrasi ion hidrogen $(\mathrm{pH})$ dan ion tanding. Transport sangat dipengaruhi oleh selektifitas pengemban/pembawa terhadap masing-masing logam. Pengemban TBP: D2EHPA 1:4 (1 M) cukup selektif untuk pemisahan logam berat dari limbahnya dengan urutan selektifitas adalah sebagai berikut : $\mathrm{Zn}>\mathrm{Cu}>>\mathrm{Ni}$.
\end{abstract}

Kata kunci : SLM, logam berat, selektifitas, pengemban, TBP, D2EHPA.

\section{RECOVERY AND SELECTIVE SEPARATIONS OF HEAVY METALS $(\mathrm{Zn}, \mathrm{Cu}$, and Ni) WITH SINERGY CARRIER USING SLM}

\begin{abstract}
Heavy metal separations $(\mathrm{Zn}, \mathrm{Cu}, \mathrm{Ni})$ had been conducted by synergy carrier, mixture of TBP (tryl phosphate) and D2EHPA (di-2 ethyl hexyl phosporic acid). The separation was carried out in SLM apparatus for 4 hours. Analysis was done by measuring the metal concentrations of external phase and receiving phase by AAS and Hidrogen concentration by $\mathrm{pH}$ meters. Based on the resulting analysis, it was known that the metals transpot was influenced by ion hidrogen concentration gradien, and counter ions. The transport also very influenced by carrier selectivity to metals. TBP: D2EHPA 1:4 (1 M) carrier was enough selective for heavy metal separations from waste with sequence as the following : $\mathrm{Zn}>\mathrm{Cu}>>\mathrm{Ni}$..
\end{abstract}

Key words: SLM, heavy metal, selectivity, carrier, TBP, D2EHPA.

\section{PENDAHULUAN}

Ditengarai hampir semua pabrik yang ada di Semarang (800 pabrik) kesemuaya mencemari lingkungan. Tak beda dengan kota Semarang, kota-kota besar di Pulau Jawa yang menjadi pusat sektor industri mengalami hal yang sama. Selain memberikan efek bersifat positif, ternyata kehadiran perusahaan industri di kota besar melahirkan problem pencemaran bersifat akut Baik air, udara maupun tanah semakin tercemar limbah. Metode pengolahan limbah yang efektif dalam memisahkan logam dari limbahnya sekaligus selektif dalam pemilahan antara konstituenkoonstituen yang ada dalam limbah logam berat menjadi tumpuan harapan

SLM dengan efektifitas dan selektifitas karena perbedaan dalam proses transport logamnya (kompleksasi, difusi (permeasi) dan dekompleksasi), dibantu oleh selektifitas pengemban menjadi alternatif yang layak.

Transpor yang dibantu pengemban melalui SLM adalah salah satu dari aplikasi penting dari kimia supermolekular. SLM dianggap gabungan ekstraksi dan pemisahan. Transpor digambarkan dengan urutan parti- si, kompleks dan diffusi. Dalam ekstraksi ion logam, molekul pungemban dalam membran membawa ion logam/spesies dari larutan umpan membentuk kompleks. Kompleks ini berdifusi ke sisi yang lain dari membran dimana dekompleksasi terjadi dan ion logam/spesies dilepaskan dalam larutan pemisah (stripping). Pengemban bebas kemudian berdiffusi balik melalui membran untuk penggunaan "cycle" yang lain (Misra, 1996). Unsur pengemban memainkan peranan penting dalam SLM.

D2EHPA merupakan pengemban penukar kation (logam positif) yang mempunyai ketergantungan terhadap $\mathrm{pH}$ larutan fasa air (karena atom $\mathrm{H}$ asamnya). Kelarutan yang rendah dalam air dan kestabilan yang besar terhadap hidrolisa menjadikan D2EHPA ekstraktan yang baik. Logam yang terekstraksi mengikuti ururtan: qiodri->ter->bi-> univalen (Spedding, 1961). Hampir semua logam terekstrak dengan pengemban ini (De, Anil K (1970). Penelitian pemisahan multi tahap logam berat dengan pengemban D2EHPA sedang penulis lakukan di Lab Kimia Analitik Jurusan Kimia Fakultas MIPA UNDIP. 
Tributil fosfat (TBP) adalah pengemban non ion (netral). TBP larut dalam banyak pelarut organik dengan sempurna, tapi mempunyai kelarutan yang rendah dalam air $1,5 \times 10^{-3} \mathrm{M}$ pada $25^{\circ} \mathrm{C}$, yang akan berkurang jika TBP diencerkan atau jika larutan airnya mengandung garam. TBP dikenal mempunyai kemampuan yang baik untuk mengekstraksi kompleks ion logam negatif, positif serta netral dengan mekanisme solvasi (spedding, 1961, De, Anil K, 1970).

Dengan menggabungkan TBP dan D2EHPA diharapkan efektifitas sekaligus keselektifitasannya terhadap ion logam berat menjadi bertambah.

Kompleks yang cukup selektif adalah kompleks logam-zat penopeng. Zat penopeng (pengompleks) yang biasa digunakan untuk menaikkan selektifitas pemisahan dengan teknik SLM adalah EDTA dan DTPA (Kojima, 1994; Nakamura, 1992, Matsuyama, 1989).

Perbedaan harga $\mathrm{K}$ dari beberapa kompleks logam, dikombinasikan dengan efektifitas dan selektifitas pengemban, diharapkan pemulihan (recovery) dan pemisahan selektifitas logam berat dari limbah menjadi optimal.

Bahan dan Metode. Garam-garam $\mathrm{Cu}, \mathrm{Zn}, \mathrm{Ni}$, (garam sulfat) (G.R.), kerosene, TBP, D2EHPA (SIGMA), PTFE (Politetrafluoroetilen-Whatman). Pemisahan dilakukan dalam seperangkat sel pemisahan SLM tunggal, seciangkan anlisa logam berat dilakukan dengan Spektrofotometri Serapan Atom (Perkin Elmer 5100 PC), $\mathrm{pH}$ meter Metrohm untuk ion hidrogen. Analisa dilakukan dengan mengukur konsentrasi ion logam dan ion hidrogen di fasa umpan dan penerima. Pemisahan dilakukan dengan pengemban sinergi campuran TBP: D2EHPA 1:4 (1 M). Membran PTFE direndam ke dalam membran cair (pengemban/pembawa sinergi campuran TBP:D2EHPA 1:4 (1M)) selama 2 jam, dan dilakukan pemisahan selama 4 jam dengan alat SLM. Penelitian dilakukan untuk mengetahui pengaruh $\mathrm{pH}$ fasa umpan dan ion tanding terhadap transport logam yang terjadi jika pembawa/pengemban yang digunakan adalah pembawa/pengemban sinergi.

\section{Hasil dan Diskusi.}

Keterlibatan Ion Hidrogen dalam transpor Logam Berat Pengaruh pH Umpan Terhadap \% Transpor.

Dalam mempelajari transpor logam berat melalui SLM yang dipelajari selanjutnya adalah pengaruh $\mathrm{pH}$ larutan umpan. Transpor logam berat ternyata tidak linier dengan kenaikan $\mathrm{pH}$. Seperti yang tampak pada Gambar 1.

Pada transpor reaktif yang dibantu senyawa pengemban, peranan ion hidrogen sangat penting. Kompleks logam berat-pengemban bisa mencapai fsa penerima dibantu oleh ion hidrogen tersebut. Sehingga bisa dikatakan bahwa selain gradien konsentrasi logam, gradien $\mathrm{pH}$ antara fasa umpan dan fasa penerima $(\mathrm{pH}$ 1) juga termasuk komponen gaya dorong transport. Jika $\mathrm{pH}$ fasa penerima dibuat konstan, pada $\mathrm{pH}$ dibawah 3, gradien konsentrasi ion Hidrogen antara fas umpan dan penerima belum berarti, sehingga transport pada $\mathrm{pH}$ ini belum optimal. Pada $\mathrm{pH} 3$ terjadi perbedaan $\mathrm{Kd}$ larutan umpan dan $\mathrm{Kd}$ fasa penerima yang optimal sehingga, pada $\mathrm{pH}$ ini transpor paling efísien. Pada $\mathrm{pH}$ diatas $3(\mathrm{pH} 4)$, gradien $\mathrm{pH}$ umpan dan penerima memang lebih besar dari $\mathrm{pH}$ umpan 3, tapi hal ini menyebabkan juga transport $\mathrm{HNO}_{3}$ (asam) sesuai persamaan 5.1 dari fasa enerima ke fasa umpan.

$\mathrm{H}^{\prime}(\mathrm{aq})+\mathrm{NO}_{3}(\mathrm{aq})+2 \mathrm{H}_{2} \mathrm{O}+(\text { D2EHPA) })_{2}(\mathrm{o})$ (D2EHPA. $\left.\mathrm{H}_{2} \mathrm{O}\right)_{2} \cdot \mathrm{HNO}_{3}(\mathrm{O})(5.1)$

$\mathrm{H}^{+}(\mathrm{aq})+\mathrm{NO}_{3}^{-}+\mathrm{nTBP}(\mathrm{o}) \quad \mathrm{HNO}_{3}, \mathrm{nTBP}(\mathrm{o})$

Akibat yang timbul adalah gradien konsentrasi asam dalam lapis diffusi umpan bertambah dan menyebabkan pengurangan $\mathrm{kd}_{\mathrm{F}}$ logam berat, sedangkan $\mathrm{kd}$ sertambah karena mekanisme solvasi .Selain itu, pada $\mathrm{pH}$ di atas 3 kemungkinan terjadi endapan cukup besar mengingat Ksp hidroksida logam berat sangat kecil

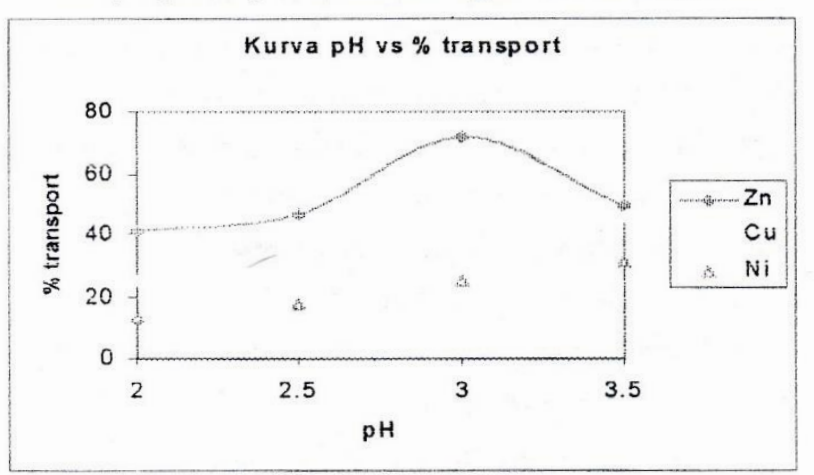

Gambar 1 Kurva Hubungan $\mathrm{pH}$ dengan \% transpor logam berat.

Dari gambar diatas dapat ditarik kesimpulan bahwa hampir semua logam (kecuali $\mathrm{Ni}$, transportnya mencapai optimal pada $\mathrm{pH}$ 3. Transport logam Ni mencapai optimal pada $\mathrm{pH}$ diatas 3, sesuai dengan kondisi optimal ekstraksi pelarut Ni dengan D2EHPA 
Sedangkan logam akan sampai di fasa penerima, contohnya adalah logam $\mathrm{Zn}$ :

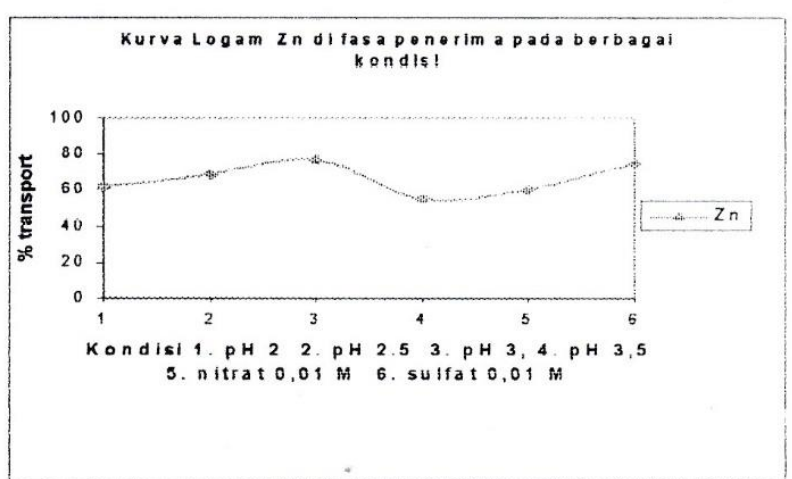

Gambar 2: Logam $\mathrm{Zn}$ yang sampai di fasa penerima pada berbagai kondisi.

Dari gambar diatas dapat dilihat pada $\mathrm{pH} 3, \operatorname{logam} \mathrm{Zn}$ mencapai transport optimal di fasa penerima.

Perubahan $\mathrm{pH}$ di fasa umpan dan penerima.

Pada transpor yang dibantu oleh pengemban penukar kation (D2EHPA) peranan $\mathrm{pH}$ sangat penting, karena dalam sistem ion tanding, ion hidrogen pada fasa penerima akan berperan sebagai pengganti ion logam berikatan dengan senyawa pengemban kemudian dilepaskan ke fasa umpan sebagai pengganti ion logam berat (Pers..3). Hal ini dibuktikan dengan naiknya konsentrasi ion hidrogen (turunnya $\mathrm{pH}$ ) di fasa umpan (tabel 1). dan turunnya konsentrasi ion hidrogen (naiknya $\mathrm{pH}$ ) di fasa penerima.

$\mathrm{M}_{\mathrm{A}}{ }^{\mathrm{n}+}+\mathrm{n}(\mathrm{D} 2 \mathrm{EHPA})_{20} \quad \mathrm{M}\left[\mathrm{H}(\mathrm{DGP})_{2}\right]_{\mathrm{no}}+\mathrm{nH}_{\mathrm{A}}{ }^{+}$

Tabel. 1.. Perubahan $\mathrm{pH}$ di fasa umpan dan penerima

\begin{tabular}{|l|c|c|c|c|}
\hline \multirow{2}{*}{ Variabel } & $\mathbf{p H}$ fasa umpan & $\mathbf{p H}$ fása peñerima \\
\cline { 2 - 5 } & $\mathbf{t}_{\mathbf{0}}$ & $\mathbf{t}_{\mathbf{4}}$ & $\mathbf{t}_{\mathbf{0}}$ & $\mathbf{t}_{\mathbf{i}}$ \\
\hline 2 & 2,05 & 2,03 & 1,00 & 1,03 \\
\hline 2.5 & 2,51 & 2,47 & 1,00 & 1,02 \\
\hline 3 & 3,01 & 2,77 & 1,00 & 1,05 \\
\hline 3.5 & 3,49 & 3,11 & 1,00 & 1,07 \\
\hline 2. ion tanding & & & & \\
\hline Nitrat $0,01 \mathbf{M}$ & 3,01 & 2,81 & 1,01 & 1,05 \\
\hline Sulfat 0,01 M & 3,01 & 2,97 & 1,00 & 1,07 \\
\hline
\end{tabular}

\section{Ion Tanding}

Dalam transport logam berat melalui ekstraksi dengan senyawa pengemban D2EHPA dan TBP akan dipengaruhi oleh ion tanding. Ada dua jenis ion tanding yang digunakan dipenelitian ini yaitu ion nitrat dan sulfat.
Dari gambar 3 dibawah terlihat bahwa, sebagian besar logam menghasilkan transport yang lebih baik jika menggunakan ion tanding $\mathrm{SO}_{4}{ }^{2-}$ dari pada $\mathrm{NO}_{3}{ }^{-}$.Ion sulfat dengan ukuran serta elektronegativitas lebih besar diandingkan ion nitrat menjadikan ion sulfat menjadi ligan yang lebih kuat daripada ion nitrat.

Ion logam akan membentuk kompleks netral dengan ion tanding kemudian bereaksi dengan ligan netral diantarmuka fasa umpan-membran dan kemudian berdifusi melalui membran. Dengan adanya gradien konsentrasi ion tanding di antara dua fasa maka kompleks yang terbentuk akan berdissosiasi diantarmuka membran-fasa penerima dan ion logam dilepas kembali di fasa penerima.

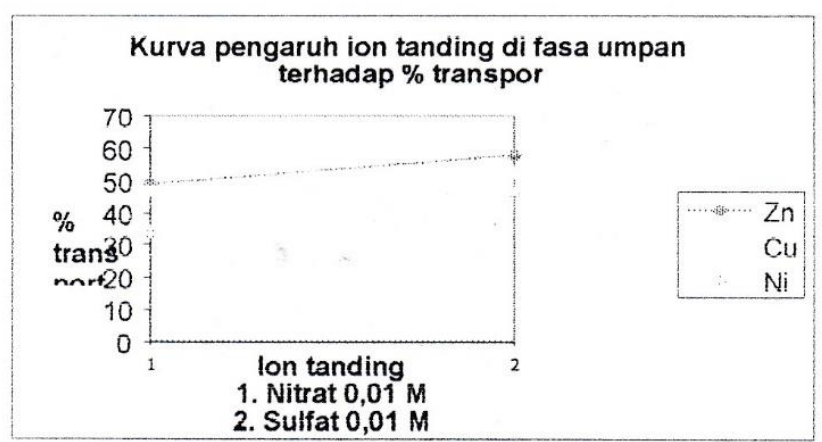

Gambar 3. Kurvạ pengaruh ion tanding di fasa umpan terhacap $\%$ transport.

\section{KESIMPULAN}

1. Selektifitas pembawa/pengemban TBP:D2EHPA 1:4 (1 M) terhadap logam $\mathrm{Zn}, \mathrm{Cu}$ dan $\mathrm{Ni}$ adalah $\mathrm{Zn}>\mathrm{Cu}>>\mathrm{Ni}$

2. Dengan pengemban/pembawa TBP:D2EHPA 1:4 (1M), transport logam optimal pada $\mathrm{pH} 3$.

3. Transport Logam dipengaruhi oleh ion tanäing.

\section{SARAN}

1. Periu dilakukan penelitian tentang kondisi percobaan sampai diperoleh pemisahan optimal ketiga logam tersebut. 